\title{
Globalization Creates New Challenges in Higher Education - Two New Educational Activities Addressing the Challenges
}

\author{
Bjoern Jaeger ${ }^{1,2}$ and Berit I. Helgheim ${ }^{1}$ \\ ${ }^{1}$ Molde University College \\ ${ }^{2}$ Curtin University, Perth \\ ${ }^{1}$ Norway \\ ${ }^{2}$ Australia
}

\section{Introduction}

This chapter explores how educational institutions are faced with changes in the modern global business environment, and how this leads to a need for changes in curricula for universities in general and for business schools and information systems (IS) schools in particular. Most of academia still uses a strict disciplinary model of education resulting in a high degree of specialization within each discipline, while modern business environments require knowledge workers who can address problems that cut across disciplines on an increasingly global scale. Both researchers and governments observing this trend have called for a change in higher education over the last decade. Although suggestions vary for what such a change should encompass, all agree that there is a need to increase the focus on the following three topics: (1) globalization, (2) collaborative skills and (3) information literacy. How to incorporate these topics into curricula has been a subject of debate and this is still an open question, but it is clear that especially topics 2) and 3) need to be based on students' experience and training instead of typical classroom lectures. We take a practical approach by introducing two new multinational educational activities to develop skills related to the three topics of globalization, collaborative skills and information literacy. Activity 1 is global supply chain management using an ERP system and Activity 2 is a Virtual Team Role Play using virtual world software. Results from several pilot studies using these techniques in two universities in Norway and Australia are discussed.

\section{Globalization creates new challenges for business and IS schools}

The development of the world economy over the last decades has been strongly influenced by the increase in international trade. According to the World Trade Organization (WTO), the yearly growth rate in international trade from 1960 to 2008 was around 6\%, which is higher than the world gross domestic product (GDP) growth rate of around $4 \%$. The latest numbers from WTO show an accelerating trend with a global trade rate expected to reach 13.5\% in 2011 (Economic Times, 2010). WTO statistics also show a shift in trade patterns among geographical areas. For example, the export rate for the least developed countries 
shows an average growth rate of more than $20 \%$ over the $2000-2008$ period, out-performing the global trends in the world trade rate of $12 \%$ growth, and in 2009 China overtook Germany as the lead exporter of merchandise, with the United States in third position. This evolution of global trade affects not only companies and countries but also the competencies needed to work in the increasingly international business environment. Competencies are defined here as a combination of theoretical knowledge and practical skills. A discussion of competencies can be found in Eurydice (2002). Universities have a long tradition in providing theoretical knowledge with a curriculum typically organized around disciplines such as accounting, marketing, operations management and organizational theory for business schools, while for IS schools typical disciplines are: data and information management, systems analysis and design, project management, and IS strategy, management, and acquisition (Topi, 2010). In this chapter we argue for adding a relatively small amount of practical skills to the curriculum in both business and IS schools. The addendum is a cross-functional approach where the practical operations performed by students are organized by the instructors according to established theories previously covered in the curriculum. This can be seen as a practical and extended variation of the capstone course principle used in many business schools, where capstone courses are used to integrate materials from different topics (Rajkumar, 2007). We do not make an explicit link between the practical topics and the previously theoretical knowledge. It is up to the student to make this connection. Our idea is that any graduate student should be able to complete the practical assignments, but the more of the foundation theory the student knows the more valuable the practical skill part will be. This is also why we target the postgraduate level, since postgraduate students are better equipped with foundation theory than undergraduates. Our aim is to combine practice and knowledge in a manner that will give students relevant job competencies.

As mentioned, the literature and investigations point in particular to three topics that should be addressed more by academia: (1) globalization, (2) collaborative skills and (3) information literacy. We discuss the skills required in general for each of these before turning to the two new activities.

\subsection{Globalization skills}

We define globalization skills as skills that give the ability to work in an international context, to see the big picture and understand how an organization works as a whole. More specifically, we use globalization in a business context related to worldwide buying and selling of goods and services. Information systems allow organizations around the world to communicate as if they were geographically collocated. Physical distance becomes less significant, organizations can broaden their supplier and customer bases to buy, transport, store, manufacture, sell and distribute products and services in a single worldwide market. Our aim is to give students a set of practical assignments that illustrate how this can typically be done by many businesses and, as an extension of this, how the global outlook opens new possibilities.

\subsection{Collaborative skills}

We define collaborative skills as the skills that give the ability to function as an effective part of a team where one understands one's own role as well as the roles of others for a common purpose or benefit. Collaborative skills are the specific ways in which actors are 
expected to behave in order to comply with norms. Having collaborative skills mean one can work together with others to achieve a goal. In principle, these could be skills for playing in an orchestra in order to reach the goal of giving a good performance. In our case, we relate this to business norms and skills for reaching business goals. Our activities make use of collaborative skills at two management levels: first at the operational level in Activity 1 when students do business transactions by exchanging formal documents like purchase orders and invoices with the goal of completing a specific sales transaction. Relevant skills are how to operate an ERP system in order to complete the business process. Second, at the tactical level, in Activity 2 a complex interaction takes place when sales and purchasing teams negotiate with the goal of closing the sale of a sophisticated product. Relevant skills are related to behavior that supports concepts like trust, sharing, belonging and respect.

\subsection{Skills related to information literacy}

We define information literacy skills as skills that give the ability to determine what information is needed, where to find it, how to get it and how to use it. Again this is from a business perspective.

The remainder of this chapter describes two particular activities that address the need for an approach to business and IS education that focuses on the ability to synthesize several techniques, giving experience to deal with various situations that one could not handle by depending on a single theory (e-Skills Demand, 2009; Harvard, 2008; Topi, 2010). We provide this by suggesting the two new educational activities 1) Global Supply Chain Management using ERP systems and 2) Virtual Team Role Play using Virtual Worlds.

\section{Activity 1: Global Supply Chain Management using ERP-systems}

The first new activity focuses on teaching Global Supply Chain Management concepts by letting students run an international value chain in cooperation with students at another university using a real ERP system provided by SAP. The demand-driven global supply chain business process role play was developed for students to collaborate in pairs to perform various purchasing and sales operations. The global supply chain shown in Figure 1 was used. This is a supply chain network for trading bikes with customer demand represented by the End Customer Demand. Molde Bike Shop does not carry any inventory, and when they receive a customer order this triggers the different operations in the supply

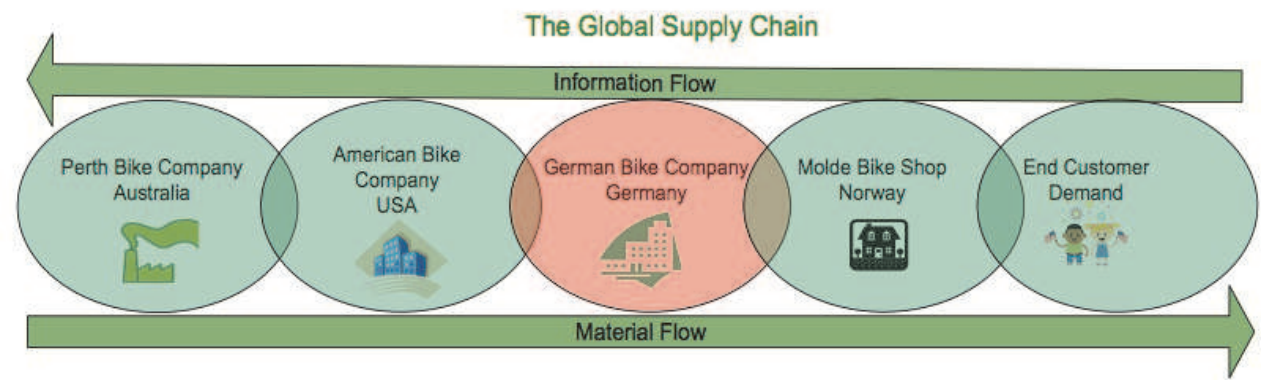

Fig. 1. Setup of the Global Supply Chain used in the SAP exercises 
chain. Molde Bike Shop sends an order to the German Bike Company, which builds a purchase order to their US supplier, the American Bike Company, which finally buys the bikes from its Australian vendor, the Perth Bike Company. The scenario played by the students is a situation where the end customer market is increasing for the particular bike product, Kids Bike, with the unique characteristic of high quality at a low price. In order to stick to the low price high quality strategy, we assume the partners have agreed to optimize the information and material flow along the supply chain. A common goal for the partners is not to carry any finished product inventory that ties capital to inventory along the chain. All partners deliver based on an incoming order.

The Perth Bike Company Australia is a fictive company that is assumed to be operated by the Australian student whose main task is to play the American Bike Company USA role. The partner, being a Norwegian student, plays the German Bike Company Germany role. The teachers play the fictive Molde Bike Shop Norway which we assume receives the End Customer Demand, and start the operation of the chain by generating purchase orders. Each role is described. For example, the role played by the Australian student in the first round is as Head of the Logistics Department in the American Bike Company, located in the US. The customer is the German Bike Company located in Germany, which means that the student must export the product from the US to Germany. The vendor is the Bike Company located in Perth, Australia. Thus the student needs to import from this company. Further, since the Head of Logistics wants to look for possibilities to decrease costs, the student is asked to run both the purchasing and selling processes. The other roles were given a similar description. Communications between the companies in the form of incoming customer order, invoicing, purchase order, invoice payment and acknowledgement are effected via e-mail external to SAP. Each company does its internal business processes in SAP. The SAP exercises consist of three main parts: initial setup of master data, procurement by doing Material Management (MM), and fulfillment of sales by doing Sales and Distribution (SD).

\subsection{Import, export and customs handling}

The SAP hands-on exercises for operating the Global Supply Chain included handling of all import and export operations. The SAP operative cockpit (SAP Cockpit, 2008) was used to guide the management of the inbound business processes (procurement, import). The cockpit shows whether replies from the customs authorities are received for any messages sent, and it keeps track of whether any follow-up actions are needed. Similarly, in the monitoring of the outbound business processes (sales, export), the cockpit was used to report status with regard to communication with the customs authorities, and of replies from the authorities or indications of business processes that need to be executed.

\subsection{Evaluation}

Activity 1 has been run three times; a pilot run and two full scale runs, in three teaching periods (February-April) in years 2009, 2010 and 2011. To evaluate the activity we used two methods; a questionnaire to measure the students' perceived knowledge gain, and discussions with lecturers at both campuses to get their perceptions and experiences. The questionnaire used was a modified version of a questionnaire developed by Seethamraju (2007) to study the design and instructional strategies in the delivery of ERP/SAP courses. It contained five knowledge dimensions: General Background, Business Knowledge, Process Knowledge, SAP Transaction Skills and Global Business Knowledge (in the questionnaire, 
Global Business Knowledge included questions on both theoretical knowledge and practical skills). The students were asked at the end of the course to report on both pre-course and post-course knowledge and skills by entering a number on a 5-point Likert scale (1 lowest, 5 highest). The responses for the Global Business Knowledge dimension from the study in 2010 were:

\begin{tabular}{|l|l|l||l|l|l|}
\hline Australia & \multicolumn{2}{|l|}{ Norway } \\
\hline Pre-Avg & Post-Avg & Difference & Pre-Avg & Post-Avg & Difference \\
\hline 3.04 & 5.05 & 2.01 & 2.00 & 5.00 & 3.00 \\
\hline
\end{tabular}

Table 1. 2010 Mean Scores of Pre- and Post-Survey for Australian and Norwegian students for the Global Business Knowledge dimension.

Both the Australian and the Norwegian students reported a perceived gain in global business knowledge with Norwegians reporting a somewhat higher gain than Australians. This may be a result of the particular cohort in Australia consisting of students in Information Systems while the Norwegians were students in Supply Chain Management/Logistics. As a result, the Norwegian students had a theoretical foundation with a closer match to the practical business operations that could explain the higher gain. Future studies will investigate this further. All results on the other knowledge domains from the pilot study in 2009 and the full study in 2010 can be found in our paper (Jaeger, 2011). Generally, the students reported an increase in competence for all the knowledge dimensions. Some students did a similar set of exercises locally with intra-university partners. Observations from the lecturers were that those students who participated in the international role play exercise performed better and showed better understanding of the transactional aspects of the sales order processing, while those working locally had some issues with the clarity of these concepts. Reasons may be that those working with international partners spent much more time with their exercises. They had to wait for their partners to post documents such as invoices and purchase orders for transactions. Having experienced being in another time zone, students had to work on their own to figure out how to organize their work better to avoid or reduce problems. The time lag, not wanted in a real business environment, became an advantage in the educational setting since it allowed students to reflect more upon the problem at hand, and since the separation of tasks enforced by the distributed operations helped to clarify the processes. The lecturers affirm the valuable experience gained on how the exercises were set up, the actual contents and the overall learning experience encountered by all parties.

\subsection{Relation to skills in globalization, collaboration and information literacy}

We illustrate how students acquire skills related to globalization, collaboration and information literacy by relating these topics to the description below of the build-up of the assignment for the sales process and the steps the students must carry out. The purchasing process follows exactly the same setup so we do not describe the details here.

Figure 2 shows the basic steps of the sales process, assuming a sell-from-stock strategy. The five steps cover the business cycle from sales order to receiving cash: first a sales order is created, then a delivery note is created before doing picking and packing followed by the shipment of the goods. The two last steps create an invoice and receive the payment. The students run sales processes first in a local environment in various ways as described below. By this they get experience in running the sales process itself. Then the students operate the sales process as part of the global supply chain. 


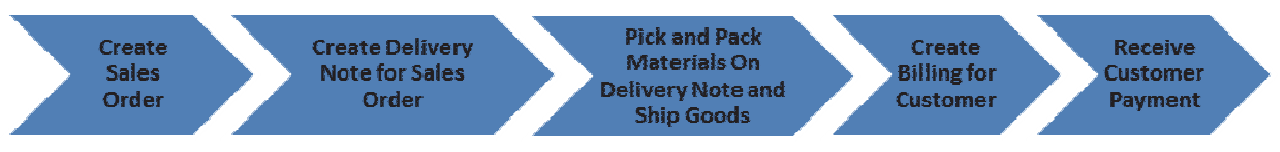

Fig. 2. The main steps of the sales process

Figure 2 is a simple figure capturing the basic steps of the sales process. However, it is a deceptively simple figure. When we add details it becomes more complex. In the assignments, students first run this process as a manual paper-based process using five documents, as shown in Figure 3.
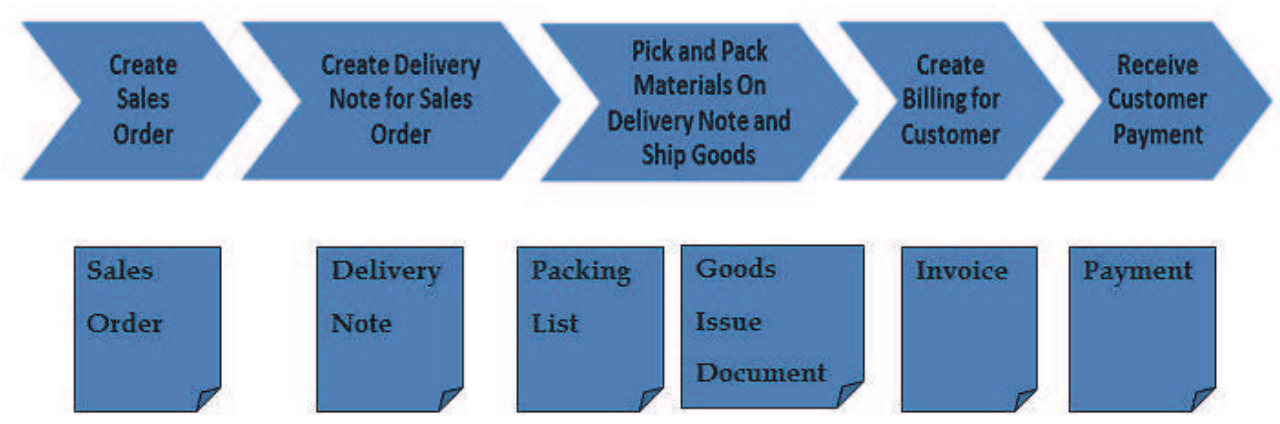
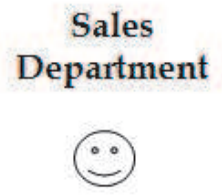
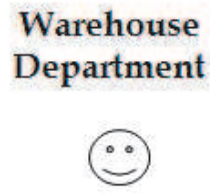

\begin{abstract}
Accounting
Department
\end{abstract}

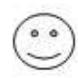

Fig. 3. Adding paper documents to run a manual sales process and typical departments involved

In a company the sales process would typically be handled by several persons in various departments, like a sales manager, a warehouse manager and an accountant: the Sales department create the Sales Order, the Warehouse the delivery note, picking and packing and shipment of goods, and lastly the Accounting Department performs the two last steps, creating an invoice and receiving the payment. The students had to play these roles filling in information by hand in each document.

Next the students run the complete sales process again, now by using the SAP ERP system playing the roles of first the sales manager, then the warehouse manager and at last the accountant. The major elements of the information flow in and out of the ERP system is illustrated in Figure 4. In step 1 the student retrieves information from the ERP system regarding the products to be entered into the sales order. Other data such as date and the person filling out the sales order are also retrieved. This is master data in the ERP system previously configured by the students in another exercise. The students enter the remaining information required to create a new sales order, typically customer details and the set of sales order lines, one for each product ordered with details of the product. The total 
information for the sales order consists of 19 data items. In step 2 the students must retrieve information from the ERP system regarding the previously created sales order to create a Delivery Note. Information for the new Delivery Note is inserted. Likewise, information is retrieved and entered into the ERP system to complete the remaining steps. By doing this the students get a hands on experience in following the information flow across the departments involved. This is a unique experience possible in an educational context since in a typical job situation in a real business each employee will only be allowed to operate the parts of the process that belongs to the responsibility of the employee in the specific department where he or she is employed.

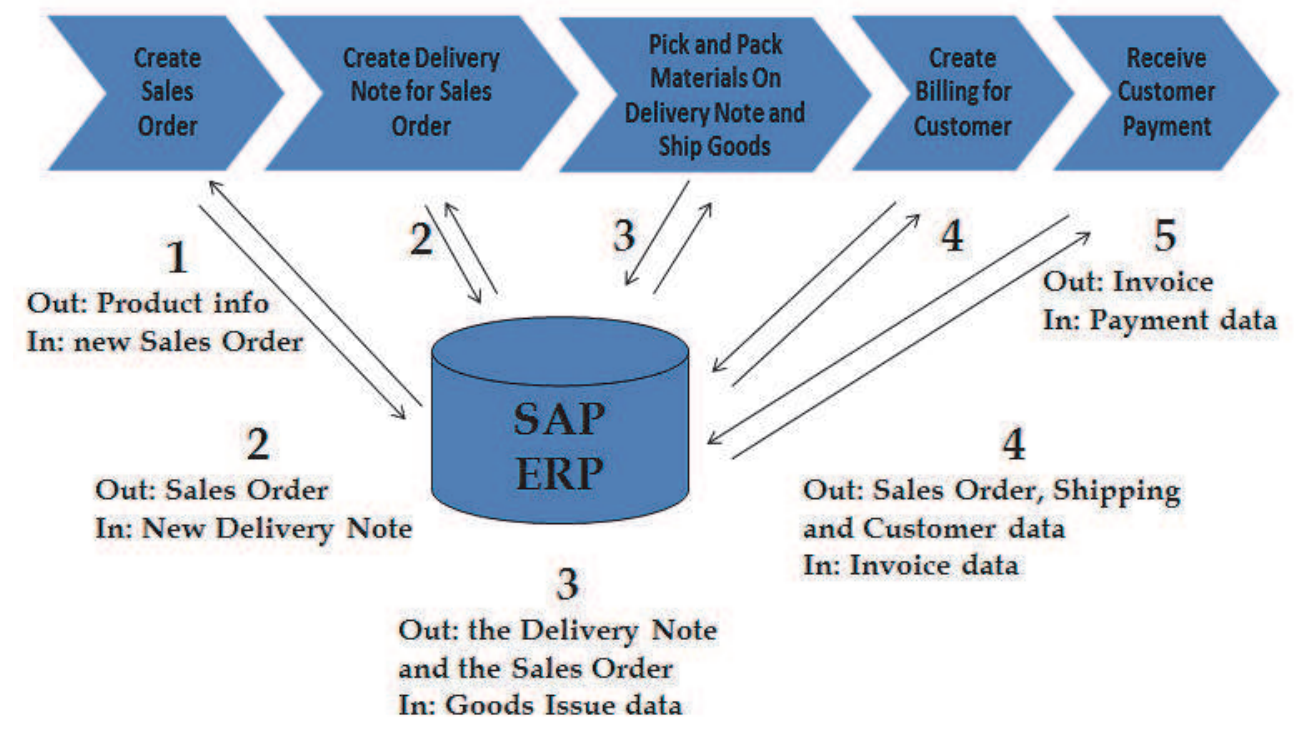

Fig. 4. Information flow in and out of the ERP-system when running the Sales Process using the SAP ERP system

The purchasing process, following a purchase-to-stock strategy, is introduced in exactly the same manner as the sales process for all students: first as a paper-based process where each student fills in paper documents, then by using the SAP ERP system to run the purchasing process. Also for purchasing each student does the job for employees in all departments when using the ERP system. That is the purchasing department, the warehouse department and the accounting department giving experience in following the information flow across the departments involved.

After the students have gained some experience in running the basic steps of the sales process as described, the students start to operate the process as part of the global supply chain adding hands on operations of export and import using the SAP cockpit. This gives experience in following the information flow across companies operating in different countries.

To do this each student is assigned a fellow student in a class at the partner university acting as a customer. The student playing the customer at the other university runs the purchasing process of the company buying (importing) the goods sold (exported) as 
illustrated in Figure 5. Both companies A and B use the SAP cockpit to support their export and import processes. The business-to-business messages are exchanged via e-mail between the companies. The "Order" in Figure 5 is a purchase order created by company A, and inserted in an e-mail that is sent to company B who based on this creates a sales order. The dotted line represents a presumed delivery of the goods ordered. Using an e-mail in the exercises simulates this. An Invoice is created in the ERP system, and sent via e-mail. Company A pays the Invoice after verifying that the purchase order, the goods receipt and the Invoice corresponds to each other. The payment is inserted in Accounts Payable in the Financial Accounting part of the ERP system. The transfer of payment usually handled by a bank transfer is simulated by an e-mail to company B who, upon receiving the e-mail, updates the Accounts Receivable in the Financial Accounting module.
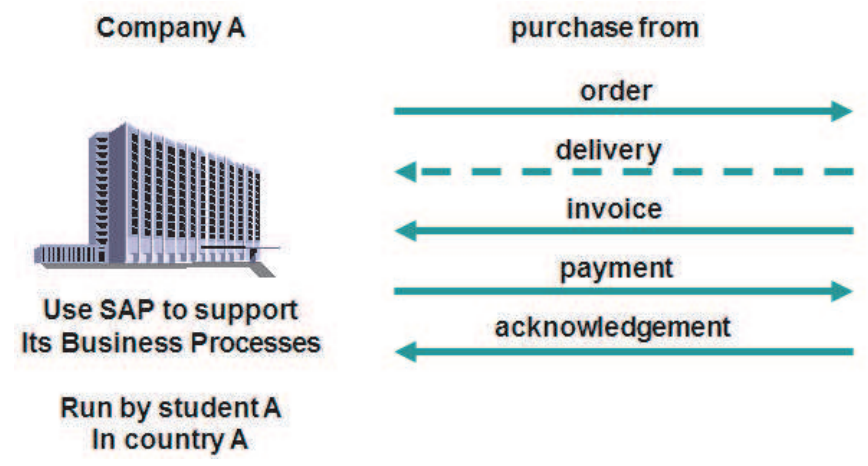

Company B

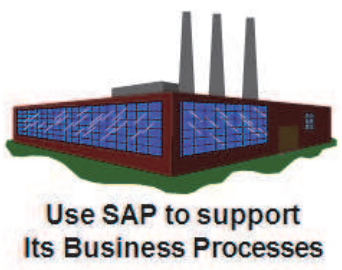

Run by student B In country B

Fig. 5. Business-to-business communication between two companies in two countries. Company A runs the purchasing process, buying (import) from company B who runs the sales process (export).

Returning to the Global Supply Chain displayed in Figure 1, we let company A be the American Bike Company located in the USA and the German Bike Company located in Germany as described above. Note that in the Global Supply Chain each student is part of a chain, and so has to do both sales (export) and procurement (import) exercises with their respective partners. This gives experience in following the information flow across several departments within the company and the related information for operating between countries.

\subsubsection{Globalization skills}

Running the paper-based process illustrated in Figure 3 shows in a clear and explicit manner the tedious work involved in a paper-based process. A student has to fill in and deliver each document he or she is responsible for and send or give it to the next student, who is responsible for another department. For this to happen in a smooth manner, they must be geographically collocated.

Introducing the ERP system in Figure 4 gets rid of the paperwork, and most importantly: the various departments can be geographically distributed; the physical distance becomes irrelevant regarding when the information is available for the next step in the process. Once a student has entered e.g. a sales order into the system, others get this information 
immediately. At this stage, the students should draw parallels to their theoretical knowledge obtained in previous classes in accounting, marketing, operations management, IS strategy, management, and acquisition. For example, using the ERP system to decouple the process from geographical locations shows how companies can outsource and offshore parts of their operation in an efficient manner. By experiencing how the ERP system makes information immediately available, they will understand that this can be an advantage for other business operations like transport, payment handling, integration with the customs authorities, and several others. Being responsible for the sales (export) and purchasing (import) processes in a company in the supply chain in Figure 1 demonstrates several issues and details when performing international transactions supported by an ERP system. This includes currency conversions, time and location adoption, consolidation across diverse accounting standards, multilingual facilities, legal control, and import-export issues. This lets the students experience how information flows along the chain, and by comparing commercial information like price and availability along the chain, they get a real experience of seeing how the price increases along the chain, for example. By using the ERP system students also get an understanding of how information exchange with authorities can be done in an efficient way and even automated for standard operation according to trade agreements. This applies in particular for students who have had classes in international business from which they should be able to draw parallels with their theoretical knowledge.

\subsubsection{Collaborative skills}

This activity makes use of collaborative skills at the operational level when students do business transactions by exchanging formal documents like purchase orders and invoices with the goal of completing a specific sales transaction. Relevant skills are how to operate an ERP system in order to complete the business process within a company across departments, and further how to collaborate with business partners (customers and suppliers) by exchanging orders and formal business messages. The communication can be said to be primarily transaction oriented: communicating information that is formal, precise, structured, and in an asynchronous manner. It is asynchronous in the sense that a response to, for example, a purchase requisition that is sent to the purchase manager via the ERP system is not expected to be responded to immediately. Each student plays the role of all departments involved in the business processes of the company the student represents; i.e. the Warehouse, Sales, Purchasing and Accounting Departments. In this way the student will get to know how his responsibility relates to the responsibility of others later on when entering a specific job in a specific department. By exchanging business messages with international partners, the students experience operating across different time zones, across different native languages with different national and international trade rules for import and export.

\subsubsection{Information literacy skills}

For this activity information literacy skills are mainly related to hands-on operation of the SAP ERP system. The student needs to log in, look up data, create master data, and perform sales and purchasing transactions, etc., by using the ERP system as illustrated in Figure 4. Skills in using other tools like word processing, e-mail and the Learning Management System to download and hand in their assignments are also required. 


\section{Activity 2: Virtual team role play using virtual worlds}

This work describes the use of a virtual world environment to facilitate a role play assignment for buying and selling Enterprise System solutions in a distributed environment. The exercise involved the use of Second Life to facilitate the virtual presentation and meeting among vendors and a purchaser of an Enterprise System. Students from Molde University College in Norway and Curtin University of Technology in Australia participate in a procurement role play involving presentations and negotiations in Second Life. This is incorporated into information systems and business classes at both universities.

Students playing sellers and purchasers were organized into teams who meet, collaborate, and negotiate business transactions in the virtual environment. In the role play a combination of open ended play and manuscript were used, letting the students fill in open parts. The students were exposed to practical experience of selling and buying ERP systems and also in operating virtual world software for business purposes. Using virtual world software like Second Life provides the students with a tool to work in an international context. Second Life, being an Internet-based virtual world, uses an avatar as the primary interaction object to represent a user. The users of Second Life can be distributed all over the world as long as they have an Internet connection. Real-time interaction is done through text, voice chatting and embedded video tools. An avatar has human characteristics, including speech and facial expressions which enables transfer of expressions in the affective domain making Second Life a suitable medium for conducting role play.

Other technology such as video conferencing is a common technology used for distance education. However, video conferencing does not support the concept of a common place to meet and interact when each participant is in a separate geographical location. Typically, the video conferencing environment facing each participant is a screen of "talking heads", each with a different background. Making efficient team presentations, performing negotiations, showing group membership and coordinating activities are difficult and ineffective in a video conferencing environment when all participants are distributed in separate places.

Virtual worlds, on the other hand, offer a common place to meet. The participants express team membership by grouping themselves together in much the same way as in real life. Analyst firm Gartner Inc (2009), commenting on the future use of virtual worlds, says: "Looking at real benefit, rather than the hyped expectations, we see a number of potentially transformational technologies that will hit the mainstream in less than five years, including Web 2.0, cloud computing, Internet TV, virtual worlds and service-oriented architecture". In year 2010 Gartner selected nTeams as that year's cool vendor. nTeams is the publisher of an enterprise virtual world solution built on top of Second Life that is designed to help widely distributed teams collaborate.

The role play in activity 2 is called Response to Request-For-Proposal for an ERP system. It has been frequently used in classes worldwide for addressing the complex issue of buying an ERP system, as described in the text book by Mary Sumner (2005). The context of the role play is a fictional mid-sized manufacturing company, Wingate Electric, which has a set of computer applications handling their information management needs. Their applications have become fragmented over time and costly to operate and maintain, and consequently the company considers buying a new ERP system to solve these problems. The company develops a request-for-proposal that describes their needs of a new system. There are three competing ERP vendors who respond to the request-for-proposal; SAP, Microsoft and Oracle. After a presentation by each vendor, Wingate Electric goes through a decision 
process to decide upon a system. During the preparation each sales team conducts a literature search together with additional activities to gather information, while the purchasing team has to set up a score matrix based on a set of selection criteria from the request proposal, and a scoring method for evaluation of alternative ERP systems. Each sales team develops a sales presentation which is made to the purchasing team, who ask questions and use the score card to record their marks. When all the sales teams have completed their presentations the purchasing team provides feedback to each sales team before announcing the winning ERP vendor.

A class using the role play can be organized into several sets of teams in many ways. As an example, one way to organize it is to have one sales team with four members for each of the three vendors (i.e. 12 students), and one purchasing team with four members representing a panel of managers from the buying company, Wingate Electric (4 students). In this way 16 students participate in each such set. The number of teams and the number of participants in each team can easily be adjusted by adding or deleting vendors and roles.

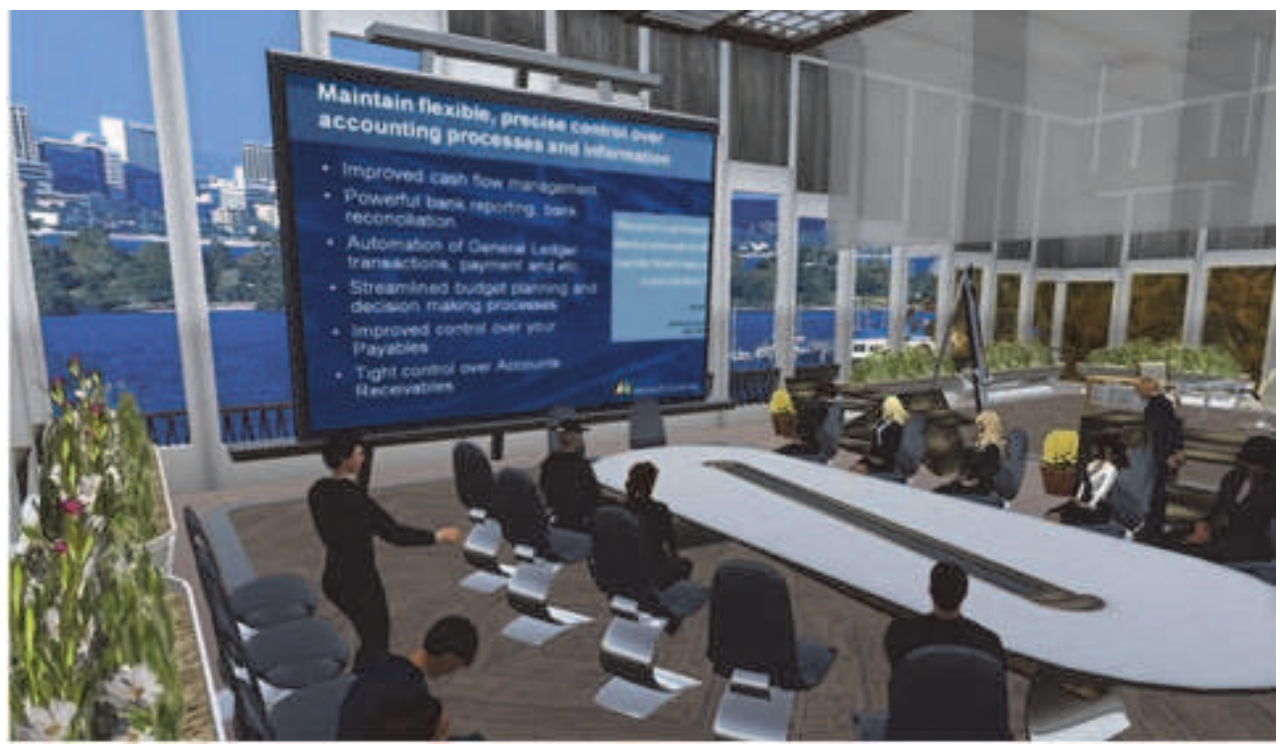

Fig. 6. Virtual meeting room for sales presentations. The Microsoft Dynamics ERP vendor is presenting their solution for the Wingate Electric purchasing team. Each participant is at a separate geographic location.

In Figure 6 all participants are at different geographic locations connected to the virtual meeting room in Second Life through a PC running Second Life. The sessions in Second Life can easily be recorded for students to review their performance and for instructors to provide feedback. The role play has been run regularly in Second Life for the last four years. Students from one class in Molde, Norway and one class in Perth, Australia participated in the same role play, forming true virtual teams. In order to make the role play as realistic as possible, the students were asked to familiarize themselves with the business etiquette and code of conduct required in business dealings and negotiations. This includes requiring avatars to have a formal dress code in a typical executive style aligned with the real world 
environment. The students in Norway and Australia did not know each other beforehand which made the virtual team role play more realistic.

\subsection{Evaluation}

Activity 2 has been run a number of times, of which three were among students at the two universities in Australia and Norway in the years 2009, 2010 and 2011. To evaluate the activity we used a qualitative approach combining three methods. A questionnaire with both numbered answer alternatives and open-ended questions was used to get an impression of student reflections on using Second Life for the role play. The second method was discussions with students and teachers at both campuses to get their view, and the third method was the use of playback of recorded sessions in Second Life to facilitate analysis of the sessions and to give feedback to students in a debriefing session. The questions were related to i) the impression of using Second Life for doing the Virtual Team Role Play and its potential for a real business situation, ii) the level of presence felt with the other geographically distributed participants, and iii) the amount of workload experienced compared with similar on-campus role plays. The results in the two countries were nearly identical. For topic i) the results showed that the students considered the role play as useful and that it could be used by real businesses. For ii) the students perceived that they got a feeling of presence, and for iii) they considered the amount of work required for the role play in Second Life as about the same or less than performing the role play at campus. A detailed presentation of the results is presented in our paper (Rudra, 2011).

\subsection{Our suggestion relates to skills in the three topics as follows \\ 4.2.1 Globalization skills}

The students participated in activities that introduced them to a collaborative tool to do negotiations in a distributed environment. These students had to organize themselves in the environment and settle into their roles. The leaders directed their group towards a common goal of selling the ERP system for the sales team, and making a purchasing decision for the buying team using imperfect information. The communication was synchronous real-time communication across several time zones. Compared to the communication in Activity 1, it can be said to be less formal, less precise, and unstructured. Second Life supports a combination of a real and a virtual presence of users. Real presence is achieved by voice communication and to some extent control of the body language including lip synchronization and a set of simple gestures of the avatar. The presence by avatars allows for simulated face-to-face interaction combined with voice, where ideas and knowledge are shared. Although still very limited compared to a real life face-to-face meeting, doing the team-oriented role play in Second Life gave the students experience of meeting in a virtual environment to conduct business negotiations.

\subsubsection{Collaborative skills}

This activity makes use of collaborative skills at the tactical level in the complex interaction that takes place when sales and purchasing teams negotiate with the goal of closing the sale of a sophisticated product. Relevant skills are related to behaviour that supports concepts like trust, sharing, belonging and respect. As noted above, we do not make an explicit link between the practical performance of the students and the theory related to collaborative skills, as this is for the student to experience, based on theory covered in previous classes. 


\subsubsection{Information literacy skills}

For this activity the information literacy skills are twofold. One relates to the management side, where skills for information handling are more open-ended than in Activity 1. This is related to handling information for business needs, product offerings and the financial situation. The second part relates to skills to operate IT tools like Second Life and standard office support software.

\section{Conclusion}

This chapter has presented two new educational activities addressing the need for educational activities that provide competencies that cuts across disciplines on a global scale. The activities are targeted at the postgraduate level in business and Information systems schools. We suggest running these activities as hands on exercises giving students practical skills in doing typical business operations at both the operational and the tactical management level of an organization doing business in an international setting. The practical skills gained in combination with the theoretical knowledge previously covered in other courses will give students competencies highly sought in the job market.

Our results indicate a gain in competencies in the three domains of (1) globalization, (2) collaboration and (3) information literacy. Activity 1, Global Supply Chain Management using ERP systems, the students had to understand both how to do the exact import and export operations in SAP and how to manage their business processes in the global supply chain.

In Activity 2, Virtual Team Role Play using Virtual Worlds, students got competencies needed at the tactical level in an organization both by operating the virtual world software, and by participating in the role play in a negotiation between sales and purchasing teams.

We believe these two new educational activities can be added to existing curricula with only small changes to the total curriculum. We think the combined effect of practical skills and theoretical knowledge will contribute to more relevant programs addressing the growing needs for these competencies by businesses and organizations.

\section{References}

e-Skills Demand (2009). e-Skills Demand Developments and Challenges, Sectoral e-Business Watch Study Report No. 05/2009.

http://www.ebusiness-watch.org/studies/special_topics/2009/documents/FR052009_eSkills.pdf

Economic Times (2010). The Economic Times, 20 Sep, 2010.

http:/ / economictimes.indiatimes.com/news/economy/foreign-trade/WTO-seesrecord-trade-growth-of-135-pc-this-year/articleshow/6595080.cms Accessed March 20. 2011.

Eurydice (2002). Key Competencies. A developing concept in general compulsory education, Eurydice, The information network on education in Europe, Survey 5. October 2002. www.see-educoop.net/education_in/pdf/compulsary-edu-oth-enl-t05.pdf Accessed April 26. 2011.

Gartner (2009). Gartner: Virtual Worlds, a Long-Term Play. Retrieved from http:/ / www.engagedigital.com/2009/08/20/gartner-virtual-worlds-a-longtermplay/ 
Gartner (2010). nTeams Named Cool Vendor By Gartner. Retrieved from http:/ / www.engagedigital.com/2010/06/03/nteams-named-cool-vendor-bygartner/

Harvard (2008). Harvard Business School Discusses Future of the MBA, Harvard Bulletin, Retrieved 23 June 2009 from http:/ / www.exed.hbs.edu/cgi-bin/wk/6053.html

Jaeger, B., Rudra, A., Aitken, A., Chang, V. \& Helgheim, B. I. (2011). Teaching Business Process Management in Cross-Country Collaborative Teams Using ERP. Accepted at ECIS-2011, Finland.

Mintzberg, H. (2004). Managers Not MBAs: A Hard Look at the Soft Practice of Managing and Management Development, Berrett-Koehler Publishers, San Francisco, ISBN: 1576752755.

Mintzberg, H. (2005). The Magic Number Seven: Plus or Minus a Couple of Managers. Academy of Management Learning E Education, Vol. 4, No. 2 (Jun. 2005), pp. 244-247. ISSN: $1537260 \mathrm{X}$

Porter, L. W. \& McKibbin, L. E. (1988). Management education and development: Drift or thrust into the 21st century? McGraw-Hill, ISBN 0070505217 New York.

Rajkumar, T. M. \& Sarma, M. (2007). Teaching ERP concepts in a Capstone Course, Ch VI, In: Enterprise Systems education in the 21 ${ }^{\text {st }}$ Century, Targowski, A. S. and Tarn, J. M., Information Science Publishing, Idea Group. ISBN 1599043491, Hershey.

Rudra, A., Jaeger, B., Aitken, A., Chang, V. \& Helgheim, B. (2011). Virtual Team Role Play Using Second Life for Teaching Business Process Concepts. HICSS-44: Hawaii International Conference on System Sciences, Kauai, ISBN 978-0-7695-4282-9, Hawaii, Jan 4-7, 2011.

SAP Cockpit (2008). Retrieved 15 June, 2009, from http:/ /help.sap.com/saphelp_gts71/helpdata/en/03/323a426ea5b26be10000000a1 55106/content.htm

SAP (2009). SAP 2009 Sustainability Report, Retrieved from www.sapsustainabilityreport.com/2009/overview/commitment Accessed April 26. 2011.

Seethamraju, R. (2007). Enterprise Systems (ES) Software in Business School Curriculum Evaluation of Design and Delivery, Journal of Information Systems Education, Vol. 18, No.1, pp. 69-84.

Sumner, M. (2005). Enterprise Resource Planning, Prentice Hall, ISBN-13: 9780131403437, Upper Saddle River, New Jersey.

Topi, H., Valacich, J. S., Wright, R. T., Kaiser, K., Nunamaker Jr, J. F., Sipior, J. C. \& de Vreede, G. J. (2010). IS 2010: curriculum guidelines for undergraduate degree programs in information systems, Communications of the Association for Information Systems, Vol. 26, No. 1, p. 18.

Wild, J. J., Wild, K. L. (2008). International Business: The Challenges of Globalization, Pearson Education, ISBN 0131747436, Cambridge, MA. 


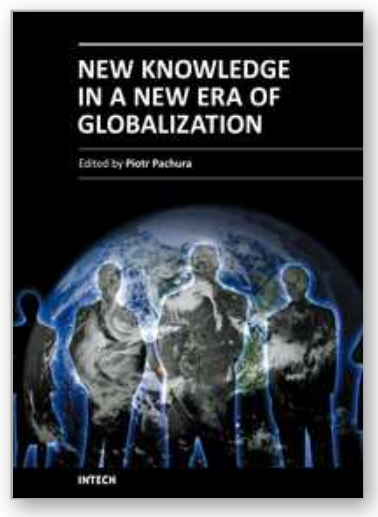

\author{
New Knowledge in a New Era of Globalization \\ Edited by Prof. Piotr Pachura
}

ISBN 978-953-307-501-3

Hard cover, 354 pages

Publisher InTech

Published online 01, August, 2011

Published in print edition August, 2011

To better understand the contemporary world, the world of innovation and technology, science should try to synthesize and assimilate social science in the development of our civilization. Does the new era require new knowledge? Does the age of globalization demand new education, new human attitudes? This books tries to clarify these questions. The book New Knowledge in a New Era of Globalization consists of 16 chapters divided into three sections: Globalization and Education; Globalization and Human Being; Globalization and Space. The Authors of respective chapters represent a great diversity of disciplines and methodological approaches as well as a variety of academic culture. This book is a valuable contribution and it will certainly be appreciated by a global community of scholars.

\title{
How to reference
}

In order to correctly reference this scholarly work, feel free to copy and paste the following:

Bjoern Jaeger and Berit I. Helgheim (2011). Globalization Creates New Challenges in Higher Education - Two New Educational Activities Addressing the Challenges, New Knowledge in a New Era of Globalization, Prof. Piotr Pachura (Ed.), ISBN: 978-953-307-501-3, InTech, Available from: http://www.intechopen.com/books/newknowledge-in-a-new-era-of-globalization/globalization-creates-new-challenges-in-higher-education-two-neweducational-activities-addressing-t

\section{INTECH}

open science | open minds

\author{
InTech Europe \\ University Campus STeP Ri \\ Slavka Krautzeka 83/A \\ 51000 Rijeka, Croatia \\ Phone: +385 (51) 770447 \\ Fax: +385 (51) 686166 \\ www.intechopen.com
}

\author{
InTech China \\ Unit 405, Office Block, Hotel Equatorial Shanghai \\ No.65, Yan An Road (West), Shanghai, 200040, China \\ 中国上海市延安西路65号上海国际贵都大饭店办公楼405单元 \\ Phone: +86-21-62489820 \\ Fax: +86-21-62489821
}


(C) 2011 The Author(s). Licensee IntechOpen. This chapter is distributed under the terms of the Creative Commons Attribution-NonCommercialShareAlike-3.0 License, which permits use, distribution and reproduction for non-commercial purposes, provided the original is properly cited and derivative works building on this content are distributed under the same license. 